\title{
ISLAMIC-SCHOOL, MICRO-POLITICS AND TYPE OF KYAI'S POLICY, BEHAVIORIAL REASERCH AND SHIFTING PARADIGM OF KYAI PESANTREN
}

\author{
Mulyadi \\ Sekolah Tinggi Agama Islam Al Azhar Menganti Gresik, Indonesia \\ E-mail: mulyadiaz341@gmail.com
}

\begin{abstract}
Abstrak: Artikel ini hadir untuk mereaktualisasi dan mereduksi paradigma baru kepemimpinan pesantren; yang sejatinya sudah banyak diteliti oleh para akademisi. Sebuah model kepemimpinan yang dipengaruhi oleh dua aspek penting; pertama, pengetahuan dan pengalaman manajerial kiai dalam mengelola lembaga pendidikan yang didirikannya. Kedua, diskursus model ideal pengembangan dan pengelolaan pendidikan pesantren, di era yang serba modern ini. Tulisan ini akan didekati menggunakan dua pendekatan teorik. Pertama, teori perilaku organisasi dan model-model kepemimpinan. Kedua, melalui teori antropologi kepemimpinan. Pendekatan teoritik kedua ini digunakan untuk mencari format ideal bagaimana semestinya kiai mengelola lembaga pendidikannya. Dari dua kerangka teoritik di atas, maka dihasilkan kesimpulan bahwa; kiai pada satu sisi - melalui pengalaman dan pemahaman manajeria terhadap perubahan sosial - bisa membangun sendiri lembaga pendidikannya, tanpa harus melihat perubahan di luar pesantren. Di pihak yang lain, sistem pengembangan budaya kolaborasi, baik internal maupun eksternal, harus juga dibangun untuk membentuk pesantren yang bertahan dari gempuran modernis. Dengan syarat, kolaborasi ini dibingkai melalui kepemimpinan yang berintegritas, konsisten, dan profetik.
\end{abstract}

Keyword: Leadership, Kyai, and School Politic

\section{Pendahuluan}

Salah satu keunikan pendidikan di Indonesia ialah, kebertahanan pendidikan sistem budaya ajar pesantren, dikala lembaga-lembaga pendidikan Islam lainnya, seperti Masjid, Zawiyah, Maktab, dll, berubah mengikuti arus zaman. Perubahan itupula, yang menghadirkan pendidikan Islam, kehilangan identitas aslinya. Berbeda dengan pesantren, kebertahanan pesantren ada pada dua ruang sekaligus; bertahan dan tidak merubah identitas aslinya. Transformasi pesantren, dieterangkan oleh 
Hanun Asrohah, menjadi empat model; selektif, instrumental, minimal, dan penuh. ${ }^{1}$ Selektif bermakna, mengadopsi sistem pendidikan modern, tanpa merubah muatan pembelajaran kepesantren. Instrumental berarti, watak asli pesantren tidak dirubah, hanya mengembangkan model madrasah untuk pengembangan bahasa. Minimal, pesantren yang dimodifikasi sebagai sistem pengasramaan, sedangkan sekolah/madrasah/universitas sebagai basis pembelajaran. Adapun transformasi penuh memiliki definisi bahwa, pesantren dan sekolah modern digabung menjadi satu kesatuan sistemik.

Tak sekedar mempertahankan model pembelajaran yang khas, dari sisi manajerial, perubahan pesantren juga beragam. Mudjamil Qomar mengidentifikasi bahwa kebertahanan pesantren juga didukung oleh kemampuan pesantren, memilih sistem manajerial. Misalnya, peadaptasian budaya dan model-model pengembangan organisasi. Dari sisi budaya organisasi, awalnya, model manajemen pesantren sangat terpusat pada sosok kiai, dan ada keengganan untuk melibatkan banyak orang dalam pengelolaan pesantren. Hari ini, peran serta dan kepemimpinan kiai tidak lagi sedominan sebelumnya. Dari sisi pengembangan, pengelolaan pesantren lebih administratif dibandingkan sebelumnya. Produk-produk tekhnologi, seperti website, komputer, dan komponen lainnya, bukan lagi hal yang asing di lingkungan pesantren. Pada bagian ini, pengembangan pengetahuan dan skill pengaplikasian teknologi menjadi sebuah keharusan. ${ }^{2}$

Penulis bersepakat dengan ungkapan Azyumardi Azra yang mengatakan bahwa, sistem kebertahanan pesantren dilalui dengan cara 'menolak sambil mengikuti'. atau sebuah maqolah yang sangat terkenal di dalam pesantren "menjaga tradisi lama yang baik, dan mengambil budaya baru yang lebih baik". Berdasarkan pada paradigma inilah, pergeseran yang terjadi di pesantren bisa dianalisa dan diperkirakan model-model antisipatorisnya. Para akademisi, sebut saja AA Karimullah, Muhammad Shodiq, dan beberapa peneliti lainnya, menganggap bahwa arus kekuatan utama di dalam pesantren ada pada sosok kiai. Dengan perbedaan kekuasaan dan otoritas yang dimiliki. Menurut Shodiq, Kiai Nasab agak sedikit

${ }^{1}$ Hanun Asrohah, Transformasi Pesantren (Jakarta: Rineka, 2003), 84

${ }^{2}$ Mujamil Qomar, Menggagas Pendidikan Islam (Bandung: Rosdakarya, 2014), 27-28

74 | Tarbiyatuna: Jurnal Pendidikan Islam; Volume 11, Nomor 1, Februari 2018 p-ISSN: 2085-6539, e-ISSN 
memiliki keterbatasan kekuasaan dibandingkan Kiai Nasib. Kiai Nasab masih terikat dengan fondasi visi, misi, dan budaya yang sudah dikembangkan oleh para pendahulunya. $^{3}$

Tulisan ini, tidak ingin sekedar mendeskripsikan kecenderungan kajian-kajian akademik, melainkan juga mengalisa bagaimana kiai melakukan proses dialektis dalam menanggapi perubahan sosial di masyarakat. Bagaimana kebijakan-kebijakan itu dirumuskan?. Apakah fondasi pemikiran yang dilalui untuk menentukan keputusan tersebut. Dalam konteks ini, tulisan ini akan didekati melalui paradigma baru kajian sosial-pendidikan dan manajemen pendidikan. Dari sisi sosiologis, Apple mengatakan bahwa ada seni politik yang bermain dalam kekuasaan sekolah. Apalagi dalam aspek Parochial School. ${ }^{4}$ Dari sisi manajerial, ada keyakinan baru bahwa, subtansi terkuat di seni manajerial adalah perilaku manusia atau kepemimpinan itu sendiri. ${ }^{5}$

\section{Pondok Pesantren; Managerialism vis a vis Leadership}

Sedikit apologetik memang, menganggap pesantren memiliki seni manajemen yang khas dan berkesesuaian dengan ilmu manajemen. Pasalnya, secara historis, eksistensi pesantren sangat bergantung pada kepemimpinan personal kyai dan kepercayaan masyarakat sekitar. Tapi, juga harus diakui bahwa, perjalanan panjang pesantren dan kepercayaan masyarakat, harus dikelola dengan baik; sekilas seperti hubungan dualitas produsen dan konsumen dalam terminologi manajemen koorporate. ${ }^{6}$ Maka dari itu, ide untuk membingkai nomenklatur manajemen pondok pesantren baru hadir setelah diskursus manajemen pendidikan juga menjadi bagian dari projek pemerintah dalam sistem pendidikan nasional. Sebagaimana catatan HAR Tilaar postur kajian manajeralisme pendidikan baru dimulai pada awal 1999an, pasca reformasi dan demokratisasi pendidikan dilakukan secara menyeluruh. ${ }^{7}$ Sejak itu pula,

3 A. M. Karim Amrullah "Perubahan Model Penyelenggaraan Pendidikan Pesantren" (Disertasi-Universitas Malang, 2011), dan Muhammad Shodiq, "Kepemimpinan Kiai Nasib dalam Meningkatkan Mutu Pesantren, Studi pada Pesantren Al-Hikam Malang, Pesantren Luhur Al-Husna Surabaya, dan Pesantren Mahasiswa An-Nur Surabya” (Disertasi--Universitas Negeri Malang, 2011)

${ }^{4}$ Stephen Ball The Routledge Falmer Reader of Sociology of Education (New York: Routledge Falmer, 2004) 3

5 Kenneth A. Leithwood, What We Know About Succesfull School Leadership (UK: National College for School

Leadership, 2003), 2

${ }^{6}$ Qomar, Menggagas, 30

${ }^{7}$ HAR Tilaar, Pendidikan dan Kekuasaan (Jakarta: Rinneka Cipta, 2003), 84 
produk kajian manajemen pendidikan seperti Manajemen Berbasis Sekolah (School Based Manajemen/MBS), Total Quality Manajemen (TQM), dan standarisasi profesi tenaga pendidikan, mulai masuk menjadi bagian kajian pendidikan secara holistik.

Kendati demikian faktanya, ada banyak postulat yang menunjukkan bahwa pesantren sudah melaksanakan tahapan-tahapan manajerial, meski mereka tidak memahaminya secara ilmiah. Postulat pertama, kemandirian pesantren dan tidak bergantung kepada suntikan dana dari pemerintah. Hal inilah yang sejatinya diharapkan pemerintah melancarkan program dan proyeksi Manajemen Berbasis Sekolah (MBS). Sebuah sekolah yang mampu mengelola seluruh proses pendidikan sendiri; mulai dari tata kelola administratif, keuangan, pembelajaran, hingga proses monitoring dan evaluasi. ${ }^{8}$ Pola dan tradisi ini, diakui atau tidak, sudah sangat melekat dalam konteks kepesantrenan. Semua alur pendidikan, pengelolaan keuangan, dan lain semacamnya, sudah dikelola sedemikian rupa; walaupun melalui cara-cara yang tradisional.

Tak ubahnya pada produk kajian Manajemen Pendidikan kedua, dimana kualitas/mutu menjadi pengarusutamaan dalam pengelolaan jasa pendidikan. Standarisasi mutu - dilakukan pemerintah melalui berbagai instumentasi, misalnya; standar operasi/proses manajeral melalui akreditasi dan sertifikasi. Buchari Alma mengatakan standard mutu pendidikan terletak pada tiga aspek penting; pertama, pembelajar, budaya akademik, dan daya tarik lain atau trade mark yang dibangun di lembaga pendidikan. ${ }^{9}$ Mutu pembelajar, secara kebijakan didiskoveri oleh adanya undang-undang profesionalitas guru. Profesionalitas bermakna kemampuan guru dalam mengajarkan dan menyampaikan bahan ajar yang sudah direncanakan. Adapun budaya akademik bermakna, proses pembelajaran yang efektif, sarana ajar yang lengkap, serta relevansi yang diajarkan sesuai dengan kebutuhan zaman. Sedangkan, trade mark bisa diartikan sebagai citera pembeda yang diciptakan lembaga pendidikan itu sendiri, semisal; sekolah yang unggul dibidang pembangunan karakter, disiplin

${ }^{8}$ Caldwell B \& S Spinks. Leading the Self-Managing School. (London: The Falmer Press. 1992), 7

9 Tony Bush, Educational Leadership And Management:Theory, Policy, and Practice dalam South African Journal of Education, Vol. 27 Copyright (C) 2007 EASA 02-400

76 | Tarbiyatuna: Jurnal Pendidikan Islam; Volume 11, Nomor 1, Februari 2018 p-ISSN: 2085-6539, e-ISSN 
keilmuan, ataupun yang lainnya. ${ }^{10}$ Lebih spesifik Muhaimin menyebut mutu ialah nilai lebih yang dimiliki lembaga pendidikan tertentu, yang di-manage dengan mempertimbangkan perbaikan input, proses, dan output. ${ }^{11}$

Dari gambaran teoritik di atas, tentu, pesantren tidak banyak melakukan proses tersebut berdasarkan pada instrumentasi teoritik. Namun secara antropologis, dapat terlihat bahwa pesantren merubah, mentransformasi, bahkan mempertahankan budaya otentik yang dimilikinya, sehingga menjadi kualitas-epic yang tidak dapat tergantikan di mata masyarakat. Hingga beberapa tahun terakhir, survey PPIM Jakarta menunjukkan adanya proses santrinisasi yang masif di kalangan masyarakat urban. $^{12}$ Hal ini dapat menunjukkan bahwa, model dan karakter pengelolaan pendidikan pesantren memiliki keunikan dan kelebihan tersendiri, hingga dianggap oleh para pemikir pendidikan sebagai format ideal untuk menyelesaikan persoalanpersoalan yang dihadapi oleh lembaga pendidikan umum. Berasaskan pemikiran itupula, menyebut pesantren memiliki pola kuasa yang kuat untuk menentukan proses pendidikannya sendiri, sebagai bagian dari cara aktif menjaga mutu, mengembangkan kualitas pengajaran, dan mengadopsi hal-hal yang lebih baik, adalah sebuah keniscayaan keberadaan cara pandang manajerial yang ada di pondok pesantren.

Postulasi kedua bahwa pesantren memiliki kerangka berfikir manajerial ialah adanya kecenderungan ilmiah yang menyebut kalau doktin manajerialisme dan proseduralisme, sudah berganti menjadi kajian kepemimpinan pendidikan. Kajian ini tidak terlepas dari banyaknya riset mengemukakan, kalau proses dan alur organisasi sangat bergantung pada cara dan model seseorang memimpin. Kenneth Leithwood dkk, Dembowski, dan Warren Bennis menyatakan bahwa paradigma manajerialisme sangat bergantung pada tampilan personal (personal apprearance) dan perlakuan untuk membentuk struktur lini serta budaya organisasi (assestment to build staffing line and cultural organazatioan) sebagai fondasi/sistem organisasi yang dipimpinnya. Oleh karenanya, kekuatan sistem prosedural, impersonal agreement, dan aturan mikanis mengikat, sangat bergantung pada kedisiplinan dan kekuasaan yang dimiliki oleh

10 Bush, Educational Leadership, 12

11 Muhaimin, Manajemen Penjaminan Mutu di Universitas Islam Negeri Malang, (Malang: UIN Malang, 2005) 11-12

12 Kenneth A. Leithwood, What We Know About Succesfull School Leadership (UK: National College for School Leadership, 2003), 2 
seorang pemimpin. ${ }^{13}$ Di pihak yang lain, masih ada paradigma makro yang menganggap bahwa birokratisasi dan sistematisasi perilaku akan lebih dominan dalam konteks penyeragaman perilaku di lembaga pendidikan. Hoy, Hanson, dan para peneliti lainnya beranggapan perilaku akan seragam apabila dijalankan melalui dua model; persuasif/coersif approaches dan centrelaisasi/desentralisasi power assestment. ${ }^{14}$ Jadi, kepemimpinan di ruang lingkup pesantren sudah lebih awal dikaji, dibandingkan proses manajerialisme pesantren. Kyai, secara definitif, adalah pemimpin pesantren dan lembaga yang dibangun dibawah naungan pesantren. Hanya saja, lagi-lagi, pola dan model kepemimpinan pesantren dianggap sebagai bagian dari proses taken from granted, tidak banyak teori-teori yang bisa dideskripsikan oleh para kyai terkait model kepemimpinan dan perilaku mereka secara ilmiah. Bahkan, karena luasnya cakupan kepemimpina kyai di Indonesia, para peneliti mendeskripsikan cenderung keluar dari space sebagai pemimpin pondok pesantren. Para kyai juga diilustrasikan sebagai pemimpin adat, pemimpin politik, hingga model-model kepemimpinan lainnya.

Dari anggapan-anggapan teoritik dan faktual di atas, maka dapat disimpulkan bahwa ada dua perbedaan unik antara diskursi dan realitas manjaerialisme pesantren, sebagaimana gambar berikut:

\section{Gambar 1.1}

\footnotetext{
13 Warren Bennis, On Become a Leader (Pheladelpia: Perceus Books Group, 2009), 1

14 Wyne K. Hoy \& Scott R. Sweetland "Designing Better School; The Meaning and Measure of Enabling School Structure" dalam Jurnal Educational Administration Quarterly Edisi No. 3, Vol. 37, 2962

78 | Tarbiyatuna: Jurnal Pendidikan Islam; Volume 11, Nomor 1, Februari 2018 p-ISSN: 2085-6539, e-ISSN
} 
Bagan Postulasi Proses dan Bingkai Manajemen Pesantren

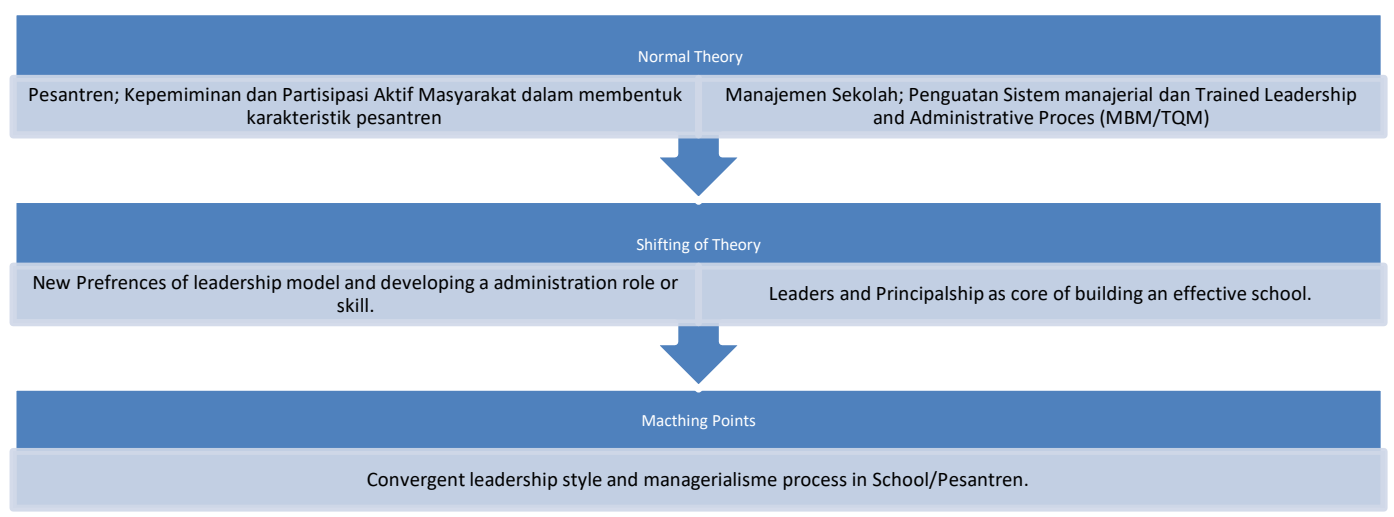

Berdasarkan bagan di atas, dapat disimpulkan bahwa manajemen pesantren secara sumber epistemnya - bersumber dari perilaku dan keyakinan kepemimpinan kyai dalam mengelola lembaga pendidikan tersebut. Tak perlu banyak aturan mengikat dan tertulis, karena pengaruh kyai terhadap santri melebih instumen mikanisme kerja formal seperti yang ada di korporasi atau birokrasi pemerintahan. Demikian sebaliknya, manajemen pendidikan cenderung mengedepankan aspek legalformal untuk membangun pengelolaan kelembagaannya, kendatipun pasca adanya gerakan kajian post-modernisme dan mikro-analisis, dalam kajian sosial-antropologis, paradigma makro itu berubah menjadi kajian pilihan rasional kepemimpina atau individual. Tapi, apakah perilaku kharismatik dan mengikat para kyai tidak diimplementasikan menggunakan cara-cara yang lebih legal-formal?. Pada tabel selanjutnya juga dijelaskan bagaimana ada pergeseran paradigma kyai dengan melakukan pengembangan struktural, kompetensi administrator, dan budaya organisasi. Hal ini dilakukan untuk merelevansikan perilaku kyai, dengan kecenderungan masyarakat modern.

\section{Educated Kyai Pesantren; a Potray of Behavirioal Politic and Social Dicisions}

Pada bagian ini penulis akan menjelaskan beberapa pergeseran paradigmatik kyai dalam mengelola pesantren. Salah satu faktor paling dominan ialah, terbentuknya kesadaran kiai akan pentingnya pendekatan ilmiah dalam membangun lembaga pendidikan. Serta, meski tidak langsung mempengaruhi, adanya aturan mengikat pemerintah untuk model-model pengembangan lembaga pendidikan formal; dimana 
pesantren modern melakukan proses integratif dalam konteks ini. Dalam hal intelektualisme kyai yang berkembang, desebutkan sebagaimana riset Mastuki HS, bahwa ada kenaikan kasta pendidikan, ekonomi, dan paradigma dari para kaum santri, ${ }^{15}$ pasca reformasi berjalan di Indonesia.

Dampaknya, kegamangan dikotomis antara pendidikan agama dan umum, tidak lagi menjadi problem untuk didiskursikan. Para kaum santri lebih cenderungan memakai pandangan integratif-differensial, integratif-holistik, atau bisa jadi, integratifselektif. Oleh sebab itulah, para pimpinan pondok pesantren, tidak mengisolasi diri, hingga bergantung pada pengetahuan tradisional yang dimiliki. Melainkan, mereka juga memberitahukan (pada ranah kognitif dan karakter), tentang kecenderungan perubahan zaman. Bagi mereka, tidak ada perbedaan mencolok; antara menjadi intelektual murni, ataupun menjadi intelektuali Islam-Tradisional. Hal yang paling penting ialah, para santri mampu berkontribusi terhadap kehidupan sosial ke masyarakatan secara nyata. Apakah itu di dunia pendidikan, pengembangan ekonomi kemasyarakatan, dan bimbingan dalam penyelarasan nilai-nilai agama di masyarakat.

AA. Karimullah lebih general melakukan kategori Kyai dan lembaga pendidikan formal yang dipimpinnya. Inovatif-Terbuka. Tipologi yang pertama ini terdapat pada pesantren yang mengalami pengembangan. Adapaun indikatornya antara lain; Kiai mendirikan sekolah; Kiai mengintegrasikan kurikulum; Kiai memberdayakan SDM; dan Kiai mengedepankan kemandirian. Tipologi yang kedua adalah Konservatif-Inovatif. Tipologi yang kedua ini terdapat juga pada pesantren yang mengalami pengembangan. Adapun indikatornya antara lain; Kiai menolak sekolah; (Kiai mengintegrasikan kurikulum; Kiai memberdayakan SDM; dan Kiai mengembangkan kemandirian. Tipologi yang ketiga adalah Terbuka-Tidak inovatif. Tipologi yang ketiga ini terdapat pada pesantren yang mengalami kemunduran. Adapaun indikatornya adalah sebagai berikut; Kiai tidak menolak sekolah; Kiai tidak mengintegrasikan kurikulum; Kiai tidak memberdayakan SDM; Kiai tidak mengedepankan kemandirian ${ }^{16}$

${ }^{15}$ Mastuki Hs, Kelas Menengah Santri (Jakarta: PPIM UIN Press, 2011), 87

16 Mastuki Hs. Kelas Menengah.

80 | Tarbiyatuna: Jurnal Pendidikan Islam; Volume 11, Nomor 1, Februari 2018 p-ISSN: 2085-6539, e-ISSN 
Pemetaan individual kiai yang bersifat antropologis di atas, membutuhkan kajian-kajian yang lebih mendalam bagaimana para kyai melakukan perubahan dan memilih untuk mempertahankan nilai-nilai yang sudah dipegang teguh lebih lama itu. Maka dari itu, penulis membuat tigakategori baru proses dialektis para kiai dan perubahan kelembagaan tersebut; pertama, kiai terdidik (educated kyai). Sebagaimana Mastuki, kategori ini didasari pada ada banyaknya kyai-pesantren yang hari ini mengenyam pendidikan modern, bergelar keilmuan pendidikan tinggi, hingga mereka juga berdialog terbuka dengan karya-karya para akademisi, untuk membangun dan mengembangkan lembaga pendidikan pesantren. Lebih-lebih dikala para pimpinan pesantren sudah memilih untuk mendirikan lembaga pendidikan tinggi Islam dibawah naungan yayasan yang dipimpinnya. Kalau melihat peta Struktural di RMI Jawa Timur misalnya, hampir semua kiai yang menjabat. Profil mereka ada yang doktor atau sedang proses menyelesaikan pendidikan doktoralnya.

Kedua, kyai dan politik pendidikan Nasional. Awalnya, penulis ingin meminjam terminologi Hiroko Horikoshi, Imam Suprayogo, dan Ali Hasan Siswanto, yang secara spesifik membahas tentang terma Kyai Politik. Namun, definisi kyai politik yang mereka kembangkan cenderung pada peran politik-praktis; atau keterlibatan para kyai untuk memberikan sumbangsih politik dalam proses perebutan kekuasaan, serta peran moral kyai untuk menjaga marwah tugas politik, para politisi muslim. Tapi, yang dimaksud terma ini, lebih spesifik. Artinya, cara kiai merespon kebijakan politik pendidikan nasional. Apakah itu dari ruang advistory kementrian Agama ataupun Kementrian lain yang menaungi lembaga-lembaga pendidikan di bahwa naungan pesantren. Pergesekan para kyai dengan aturan normatif, secara langsung dapat dipastikan, akan mempengaruhi sikap politis kyai dalam pengelolaan lembaga pendidikan di pesantren. Standarisasi input, proses, dan output - seluruh penting elemen pendidikan - akan merubah cara kyai memimpin pendidikan pesantren. Misalnya, merekrut orang-orang profesional di bidang-bidang tertentu, melatih para santri dan ustadz untuk memahami aturan baru, hingga mengikuti aturan standar yang diberlakukan ke seluruh lembaga pendidikan Islam.

Ketiga, kyai-Sosiologis. Sama halnya dengan sebelumnya. Kyai sosiologis bukan bermakna bahwa kiai merupakan produk kultus sosiologis di masyarakat 
Indonesia. Kyai-sosiologis bermakna bahwa adanya kecenderungan kiai merubah dan mengembangkan sistem pendidikan yang dipimpinnya lebih karena keinginan dan kepercayaan masyarakat sekitar, terhadap sistem baru yang ada di sistem pendidikan. Misalnya, adanya keinginan masyarakat Indonesia untuk mengedepankan sistem pendidikan vokasi dibandingkan sistem pendidikan keilmuan. Sistem pendidikan vokasi (baca; SMK), sudah bukan lagi lembaga asing di Pondok Pesantren. Belum lagi, hal tersebut didukung oleh sistem budaya kemandirian yang ada di pesantren. Kendati demikian, perubahan dan pengembangan tersebut, harus pula diakui sebagai cara berfikir progresif para kiai untuk menanggapi keinginan masyarakat sekitar. Penulis mencatat, ada fenomena menarik, kala pesantren mendirikan pendidikan vokasi, yaitu; bertambahnya jumlah santri, serta kecenderungan orang tua untuk menitipkan anaknya di lembaga baru tersebut.

Dari tiga kategori tersebut, terlihat jelas, bagaimana cara kyai merubah lembaga pendidikan pesantren beradaptasi dengan seluruh perubahan dan dinamika sosial, politik, dan ilmu pengetahuan di masyarakat. Oleh karenanya, cara mengelolanya pun tidak lagi sesederhana pada dua pola; nasab vis a vis nasib, sikap terbuka, inovatif, vis a vis tertutup dan selektif. Tapi, lebih pada cara pandang yang holistik bergantung pada bingkai-bingkai yang mempengaruhi kyai dalam proses pengembangan kelembagaannya. Misalnya, latar pendidikan, pemahaman terhadap aturan politik yang berkembang, serta keinginan masyarakat untuk melakukan perubahan sistem yang ada di dalam pendidikan pesantren.

Berdasarkan pada analisa lanjutan, pola perilaku di atas bisa dibagi sebagaimana berikut;

Gambar 1.2

Latar, Fitur, dan Perilaku Kepemimpinan Kyai 

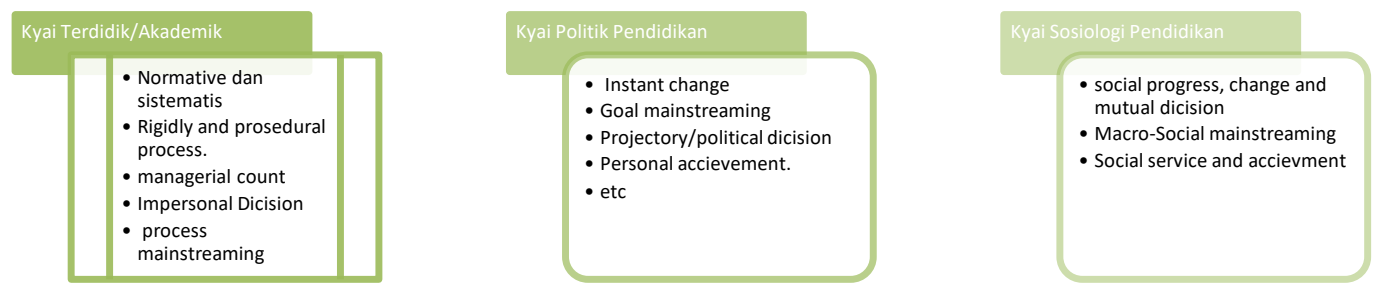

Framing perilaku kiai dalam tabel di atas, berlandaskan pada cara pandang Peter Ribbin yang mengatakan bahwa setiap proses kepemimpinan yang dilaksanakan dalam sebuah organisasi lebih kuat dipengaruhi oleh pengalaman dan pengetahuan yang dijalankan beberapa tahun berlangsung. Dalam konteks ini, dia juga menghadirkan beberapa pengalaman para kepala sekolah yang harus berhadapan dengan problem-problem tertentu di sekolah masing-masing. Semisal, kekuatan politik yang dihadapi, pengaruh supporting moral yang dihadirkan di keluarga, pengalaman hidup menghadapi masalah pelik, dan yang paling besar bisa disistematisasi pada bingkai etnografi, adalah pengalaman pengetahuan yang dihadapinya. ${ }^{17}$

Mukhlisah AM, mengatakan bahwa Pemaknaan sederhana kepemimpinan di era post-standarisasi (leadership in age of post-standararisation) adalah perubahan paradigmatik dari public-disclosure ke self-disclosure. Artinya, kepemimpinan tidak hanya disadari sebagai reduksi pengungkapan publik (masyarakat) bahwa seseorang sudah menjadi pemimpin (leader), melainkan pengungkapan dan refleksi individu (selfreflection) tentang apa pengaruh yang sudah ia berikan kepada pengikutnya. Hal terpenting dalam kajian ini adalah inovasi dan kreatifitas. Seorang pemimpin, pada era post-strandarisasi, harus mampu menterjemahkan lingkungan kerja yang mereka pimpin dan melakukan perubahan-perubahan, serta mencipta suasana baru based on creativity) yang membedakan dengan organisasi yang lain. Karakteristik pengkajian kepemimpinan, berdasarkan kesadaran diri, juga dilakukan oleh Warren Bennis. Warren Bannis, dalam on becoming leader menekankan bahwa menjadi pemimpin bukan dikarenakan proyeksi sains dan ilmu pengetahuan, melainkan karena mereka paham basic kultur dan struktur, dirinya (knowing his self), lingkungannya (knoning his

${ }^{17}$ Mukhlisah AM, "Post-Standarisasi Kepemimpinan Pesantren”, Jurnal Kependidikan Islam, Vol. 2, No. 4, 67. 
world), dan mampu mengoprasikan visi, misi, dan tujuannya (operating). Warren Bennis juga mengatakan "letting the self emerge is esential task for leader". Dia mengutip pun mengukip ungkapa Kurt Lewin "if you want to truly understand something, try to change it" ${ }^{18}$

Adapula ungkapan yang menyebut; Leadership is specific to the particular situation under investigation. Who becomes the leader of a given group engaging in a particular activity and what the leadership characteristics are in the given case are a function of the specific situation, including the measuring instruments employed. There is a wide variation in the characteristics of individuals who become leaders in similar situations, and an even greater divergence in leadership in different situations ${ }^{\text {"19 }}$ Berdasarkan pada asumsi teoritik ini, Mukhlisah menganggap bahwa kepemimpinan kiai, dengan sekian banyak tajuk klasifikasi teoritik dan temuan di lapangan, merupakan wujud dari dialektika individu kiai dan kondisi sosial yang dihadapi. Perubahan pondok pesantren yang cepat beradaptasi, mengadopsi, dan menorobos batas-batas tradisi, merupakan sebagian nilai yang diyakini dalam diri seorang kiai. Atau bahkan, sikap kepemimpinan kiai menjaga serta memelihara konservatisme bukan berarti kiai tersebut tidak mampu menilai keadaan di luar lembaga pendidikan Islam yang dipimpinnya. Melainkan, itulah sikap kekokohan sikap kiai dalam memimpin pesantrennya.

Gagasan Mukhlisah di atas, menurut penulis mengatakan bahwa kepemimpinan kiai; pertama adalah experiental leadership. Yakni seorang pemimpin yang kaya pengalaman. Sebagaimana diketahui, seorang kiai - dalam proses menuju suksesi kepemimpinan - mereka selalu melakukan riblab intelektual dan spiritual ke beberapa pondok pesantren. Hal ini pernah dideskripsikan oleh KH. Azzaim Ibrahimy pada penulis. Sebelum menjadi pemimpin atau pengasuh, beliau harus belajar ke beberapa pondok pesantren modern, salaf, bahkan konfrehensif. Beliau melakukan riblah dari lembaga lokal hingga nasional. Fenomena kiai melakukan riblah intelektual dan spiritual ini, rupanya, menjadi tradisi khusus kiai untuk mentasbihkan 'anak' atau keluarganya memimpin pondok pesantren yang dikelolanya.

Kedua, eksperimental leadership. Tipologi ini lebih sederhana dideskripsikan. Pasalnya, secara antropologis, terdapat banyak evidence dan postulat ilmiah yang

18 Mukhlisah AM, Post-Standarisasi, 68-69.

${ }^{19}$ Clive Dimmock et. al, Educational Leadership; Culture and Diversity (London: Sage Publication, 2005), 21

84 | Tarbiyatuna: Jurnal Pendidikan Islam; Volume 11, Nomor 1, Februari 2018 p-ISSN: 2085-6539, e-ISSN 
menyebut bahwa seorang kiai di pesantren selalu melakukan perubahan dengan cara mengadopsi, mengadaptasi, dan memperbarui lembaga-lembaga pendidikan di bawah naungan kultur pesantren. Seorang kiai tak 'segan-segan' merubah lembaga pendidikann formal mereka. Misalnya, memasukkan idiom 'Sekolah Islam Unggul' dan “Sekolah Menengah Kejuruan”, bersamaan dengan maraknya item ini di masyarakat urban (perkotaan). Kiai juga seringkali melakukan eksperimentasi pendidikan berdasarkan pengalaman kiai lain. Contoh sederhana, misalnya, KH. Agus Ali Tulangan Sidoarjo. Saat ini, beliau sedang mencoba corak baru idiom pendidikan Islam bernama SMP Progresif Bumi Sholawat. Sebuah sistem pendidikan yang mengintegrasikan intelektualitas dan spiritualisme. Eksperimentasi juga dilakukan di PP. Terpadu Arrisalah Lirboyo Kediri. Berdasarkan pengalaman studi banding teman penulis di pondok pesantren tersebut, menjelaskan bahwa pertama-tama pengasuh PP. Arrisaslah mengadopsi konsep Sekolah Unggul di Jombang, rupanya, sistem itu gagal diimplementasikan dengan baik. Akhirnya, meniru sistem kedisiplinan PP. Darussalam, Gontor. Itupun juga gagal. Akhirnya, PP. Arrisalah, mengimplementasikan sistemnya sendiri mengambil hal yang baik dari Jombang dan Gontor.

Semua gagasan tersebut, merupakan sebuah transformasi pemikiran antologis kepemimpinan kiai dalam konteks pendidikan dan kelembagaan pondok pesantren. Kendati konsepsi-konsepsinya akan sangat mudah dimentahkan oleh postulasi model-model kepemimpina yang dipraktekkan di beberapa pondok pesantren yang lain. Pada kesimpulannya, kerangka dasar kepemimpinan pesantren sangat bergantung pada kerangka berfikir, pengalaman, pengetahuan spiritual kiai, dan progresifitas dialogis dengan teman sejawat di luar pondok pesantren, serta supervisi pemerintah melalui regulasi-regulasi yang baru, maka kiai pesantren memiliki caracara/treatment baru dalam hal pengembangan pondok pesantren.

\section{Kyai Developmentary Policy; Learning From Kyai Leadership}


Di atas, sudah dijelaskan bagaimana proses-proses pengembangan pondok pesantren dari kerangka teoritik yang dibingkai oleh banyak peneliti; spesifiknya mereka yang concern terhadap disiplin ilmu manajemen pondok pesantren dan lembaga pendidikan Islam. Berikut ini adalah beberapa aspek baru yang menjadi trending pengembangan pondok pesantren, berdasarkan pada strategi pengembangan yang ditawarkan kepada pondok pesantren;

Dalam konteks manajemen, teori birokrasi dan organizational theory adalah pintu masuk utama menghadirkan karakteristik educational management. Hoy and Sweetland, mengatakan bahwa:

"like or not, schools are bureaucracies—they are structures with bierarchy of authority, division of labor, impersonality, objective standards, technical competence, and rules and regulations....claimed that bureaucracies are capable of attaining the bighest degree of administrative efficiency". 20

Selain itu, pada perkembangannya, ada budaya baru yang kemudian diadopsi oleh lembaga pendidikan sebagai penggabungan dari kompenen nirlaba dan pelayanan masyarakat. Perkembangan teoritik itu, diungkapkan oleh Buchari Alma dan Rhenald Kasali, sebagai budaya korporasi. Sebuah budaya yang mengedepankan aspek kepuasan kepada masyarakat dan diatur secara terbuka (open system). ${ }^{21}$ Fenomena yang demikian, sebagaimana ulasan Mardiyah, terlihat di PP. Tebuireng Jombang, berikut ini adalah hasil riset Mardiyah tentang tipologi administratif yang dibangun oleh KH. Sholahuddin Wahid semenjak terpilih sebagai Pengasuh Pondok Pesantren Tebuireng Jombang.

"...kepemimpinan Kiai Salahuddin, memiliki tipologi the broker karena ia selalu mengorientasikan layanan (service-oriented person)kepada ustadz, guru, orang tua, para alumni dan organisasi masyarakat yang dekat hubungannya dengan sekolah, agar terjalin kemitraan yang saling menguntungkan dan membantu tujuan pendidikan yang diarahkan pada perbaikan mutu belajar santri/murid. KH.Salahuddin, dikenal oleh komunitas pesantren sebagai pimpinan pesantren yang senantiasa bersikap merendah tetapi ulet dalam memperjuangkan visi pesantren dan obsesinya. Ia bersikap terbuka dan siap

\footnotetext{
${ }^{20}$ Wyne K. Hoy \& Scott R. Sweetland "Designing Better School; The Meaning and Measure of Enabling School Structure" dalam Jurnal Educational Administration Quarterly Edisi No 3 Vol 37, 296

${ }^{21}$ Buchori Alma dan Ratih Hurriyati, Manajemen Corporate dan Strategi Pemasaran Jasa Pendidikan Fokus Pada Mutu dan Layanan Prima, (Bandung; Alfabeta, 2009), 48 bandingkan dengan Rhenald Kasali, Change, (Jakarta: Gramedia Pustaka Utama, 2005), 272
}

86 | Tarbiyatuna: Jurnal Pendidikan Islam; Volume 11, Nomor 1, Februari 2018 p-ISSN: 2085-6539, e-ISSN 
untuk dikritik asalkan demi kebaikan bersama dan menguntungkan semua fihak dan pesantren. Ia senantiasa mengutamakan layanannya kepada kepentingan santri/murid (pupil service-oriented) sehingga menimbulkan simpati semua pihak untuk mendukung program-programnya yang dinilai menguntungkan santri/murid...."22

Mardiyah menambahkan bahwa, kepemimpinan KH. Shalahudin Wahid di Tebuireng juga dimulai dengan proses restrukturisasi kelembagaan and staffing line pondok pesantren. Dari sisi kelembagaan, KH. Shalahudin Wahid, selanjutnya disingkat Gus Shalah, membuat sistem informasi satu pintu. ${ }^{23}$ Jadi, seluruh informasi tentang PP. Tebuireng dan lembaga yang dinaungi oleh pondok pesantren, bisa diketahui melalui Kepala Kantor Kepesantrenan. Selain itu, dia juga mengangkat tiga wakil pengasuh dari jajaran profesional; kepesantrenan dikelola oleh Gus Ghafar, lulusan Teknik, teman semasa kuliah di ITS, dibantu oleh Gus Zaki dan KH. Mustain Syafi'i. Bidang pendidikan Gus Thoha dan Lembaga Penjaminan Mutu, Nur Hannan.

Dalam observasi penulis, pada konteks penelitian yang berbeda, kesan birokratis dan pelayanan optimal terlihat sangat jelas. Pada tahun 2011, penulis pernah ke Tebuireng untuk penelitian 'Gender, Kepemimpinan Perempuan, dan Pandangan Kiai'. Surat izin penelitian disahkan oleh Kepala Kantor dan dilayani oleh seluruh lembaga yang menjadi objek penelitian dengan sangat baik. Pada tahun 2014, penulis kembali ke Tebuireng untuk bertemu dengan Gus Sholah. Sama seperti sebelumnya, hirarki administrasi harus dilalui lebih dulu, hingga mendapatkan persetujuan dari pihak-pihak yang bersangkutan. Terkecuali, bagi para tamu, wali santri, dan orang-orang yang tidak memiliki kepentingan formal bisa langsung bertemu dengan Gus Shalah.

Selain merubah/mengembangkan budaya birokratis, adapula pesantren yang hari ini mengimplementasikan proses politik mini pemerintahan. Modal seperti ini, sebenarnya, pola adaptif yang dilakukan para kiai untuk lebih memberikan ruang pengalaman kepada para santri memahami kehidupan nyata di masyarakat. Fakta ini penulis temukan di PP. Langitan, Tuban. Sepeninggal Pengasuh kedua, KH Abdul Hadi, (alm) KH. Abdullah Faqih - yang dikenal memiliki kedekatan dengan dunia

22 Mardiyah "Kepemimpinan Kiai dalam Pemeliharaan Budaya Organisasi di Pondok Modern Gontor, Lirboyo Kediri, dan Pesantren Tebuireng Jombang” dalam Jurnal Tsaqafah, No. 1, Vol. 8, 2012, 84

23 Mardiyah, Kepemimpinan Kiai dalam Memelibara Budaya Organisasi (Malang: Aditya Media Publishing: 2012), 341344 
politik, membentuk sistem kelola pondok pesantren (baca; kepesantrenan) berbentuk sistem pemerintahan. Mereka (para santri) memiliki kekuasaan (otoritas) kuat untuk menentukan proses pembelajaran, jumlah biaya yang dibutuhkan, sistem karir dan pemilihan ketua Idarah al 'am, dst. Hingga hari ini, pola demikian dilakukan dan diimplementasikan.

Secara hirarkis-struktur pola manajerial di Langitan sebagaimana berikut;

1. Majelis Pengasuh sebagai penentu kebijakan tertinggi

2. Majelis Perwakilan Santri

3. Ketua Idarah 'Am sebagai penanggung jawab seluruh aktifitas pondok pesantren

4. Ketua Idrah Khas (Kepala Wilayah)

5. Ketua Ikatan Alumni Langitan

Postulasi model pengembangan ini bisa dilaksanakan di Langitan, karena hanya ada satu kebijakan kultural yang harus menjadi fondasi para penerus dan pengurus Pondok Pesantren Langitan "Jangan pernah merubah sistem pendidikan yang sudah ada. Boleh memasukkan yang baru, asal tidak mengganggu subtansi yang sudah lama". Atau bahasa yang paling terkenal adalah "al Mubafadzah 'ala Qhadim al Shalih, wa al 'akhdu bi al Jadid al Ashlah". Jadi, para penerus dan pengurus hanya perangkat operasional dari tanaman model yang diwariskan turun menurun tersebut.

Semenjak kecenderungan baru yang mulai menggejala di masyarakat urban di Indonesia. Banyak lembaga pendidikan Islam di kota-kota besar bertransformasi menjadi sekolah Islam unggul guna memenuhi ekspektasi dan animo masyarakat yang semakin meningkat. Penelitian Azyumardi Azra dan Arif Subhan menunjukkan hal tersebut. Azyumardi Azra mengendus adanya proses 'santrinisasi' ${ }^{24}$ masyarakat urban (perkotaan) dengan cara mendirikan 'Sekolah Islam Unggul'. Di Jakarta ada beberapa contoh sekolah Islam Unggul/Unggulan seperti Sekolah Al Azhar, SMA Insan

\footnotetext{
${ }^{24}$ Istilah santrinisasi yang dimunculkan Azyumardi Azra berasal dari tiga konstruksi dasar, pertama, murid atau siswa sekolah-sekolah Islam unguulan telah mengalami reislamisasi. Kedua, murid atau siswa membawa Islam yang mereka pelajari kerumah atau masyarakat. Kecenderungan orang tua siswa memasukkan anaknnya kesekolah Islam dikarenakan adanya fenomena destruktif di lembaga pendidikan umum seperti tauran, sex bebeas dan lain sebagainya. Lihat Azra, Pendidikan, 90.
}

88 | Tarbiyatuna: Jurnal Pendidikan Islam; Volume 11, Nomor 1, Februari 2018 p-ISSN: 2085-6539, e-ISSN 
Cendikia Serpong, Al Izhar, dan beberapa madrasah-madrasah unggulan lainnya. ${ }^{25}$ Arief Subhan juga menangkap fenomena ini dengan mengatakan;

"...sekolah-sekolah Islam bermunculan sebagai fenomena perkotaan Indonesia abad ke-20. Muhammadiyah jelas merupakan organisasi terdepan dalam konteks munculnya istilah "Sekolah Islam" yang lebih berkonotasi perkotaan....Perbedaan utama antara sekolah Islam dengan madrasah terletak pada departemen yang melakukan supervisi. Sekolah Islam berada dibawah supervisi Departemen Pendidikan Nasional...Akan tetapi, berbeda (pula) dengan sekolah pada umumnya, lembaga pendidikan ini menambahkan pendidikan keagamaan dengan porsi yang cukup besar. Perbedaan antara sekolah Islam dengan madrasah dan pesantren terletak pada penekanannya kepada aspek praktis pendidikan spesifik (seperti pembelajaran ilmu Sharaf, Nabwu, dan konteks kajian tradisionalisme lainnya, pen)...Sekolah Islam ingin mencetak pelajar-pelajar muslim yang memiliki kepribadian religius dan modern. Dalam konteks ini, Islam tidak mendapatkan penekanan pada aspek kognitif, tetapi pada aspek praktis. Penegakan Islam sebagai etika sosial mendapatkan perhatian". ${ }^{26}$

Arif Subhan menambahkan bahwa pertumbuhan "Sekolah Islam" memiliki ciri khas proses santrinisasi (berdasarkan pada sistem pengasramaan) ini pun berkembang di beberapa daerah, Sekolah Islam Al Azhar memiliki cabang-cabang yang tersebar hampir di daerah Jabodetabek. Ada pula SMA Insan Cendikia, SMA Madani dibawah Yayasan Paramadina dan beberapa daerah lain di luar Jawa dan Jakarta. Sekolah-sekolah ini memiliki air-conditioning, perpustakaan berbasis tekhnologi komputer, sarana olahraga, laboratorium, komputer, internet, dan -tentu saja- sistem belajar mengajar yang “terorganisir dengan baik", termasuk kegiatan ekstrakulikuler. Sekolah islam juga dikelola kaum profesional, baik dalam aspek manajemen maupun pengembangan kurikulum. Guru, manajer, dan staf administrasi di jaring melalui seleksi yang sangat kompetitif dan pada umumnya mereka adalah tamatan universitas terkemuka di indonesia. ${ }^{27}$

Bagaimanakah respon pesantren untuk menjawab kecenderungan ini. Atau dalam bahasa yang lebih ekonomis, bagaimanakah pondok pesantren menyediakan lembaga pendidikan yang cocok bagi kelompok masyarakat menengah ke atas.

\footnotetext{
25 Azra, Pendidikan, 89.

${ }^{26}$ Subhan, Lembaga, 138.

${ }^{27}$ Subhan, Lembaga, 140.
} 
Akankah pondok pesantren mampu menyediakan proses pendidikan yang lebih kompettif, efektif, dan profesional?. Jika mau memotret gejala maraknya Sekolah Islam Unggul - bukan madrasah, di pondok pesantren mungkin cukup jarang ditemukan. Pasalnya, concern pondok pesantren lebih condong mengembangkan madrasah dibandingkan dengan sekolah. Hal ini pun cukup beralasan, hasil survei Lembaga Survei Indonesia (LSI) menyebutkan bahwa mayoritas peserta didik di madrasah berasal dari kultur Nahdlatul Ulama' dan memiliki pemahaman keislaman yang cukup kuat. Sedangkan mereka yang memilih sekolah Islam atau sekolah umum berasal dari keluarga yang afiliasi organisasinya adalah Muhammadiyah atau tidak terikat dengan organisasi. ${ }^{28}$ Di Surabaya saja hanya ada satu madrasah unggulan bertaraf internasional yang tata cara pengelolaan dan pendidikannya berbasis pondok pesantren, yakni PP. Pesantren Amanatul Ummah. Meski kelas unggulan mereka ditempatkan di Pacet Mojokerto, yang jauh dari hiruk pikuk keramaian kota.

Meskipun jarang, bukan berarti tidak ada, sebagaimana karakteristiknya, pondok pesantren akan terus berusaha berbenah dan memperbaiki kualitas pendidikannya. Kepentingannya adalah membangun konsep tradisionalisme yang terintegrasi dengan persoalan modern. Thesa ini sempat diungkapkan oleh Prof. Dr. Imam Bawani pada proses perkuliahan "Perbandingan Pendidikan Islam" di Perkuliahan Umum Program Doktoral Pascasarjana UIN Sunan Ampel Surabaya. Beliau mengatakan bahwa "Dulu, kalau mau melihat contoh sukses pondok pesantren modern ada di Gontor, tapi saat ini, sudah tidak lagi. Ada pondok di Lirboyo kediri yang anak-anak didiknya mampu menghafal al-Qur'an, membaca kitab kuning, berbahasa asing dengan bagus, dan mumpuni di bidang pengetahuan umum. Pondok Pesantren Salafiyah Terpadu Arrisalah namanya. Inilah contoh ideal integralisme tradisionalisme pesantren dan pengetahuan umum". ${ }^{29}$ Secara observasional, pasca penulis melihat website resmi pondok pesantren ini memang memiliki keunikan tersendiri. Pondok Pesantren ini tidak memiliki pendidikan formal agama (baca; madrasah), kecuali Madrasah Diniyah. Prestasinya pun mentereng baik

\footnotetext{
${ }^{28}$ Makalah Simposium Internasional Madrasab In Global Context Puslitbang Depag Tahun 2013 Di Bekasi Jawa Barat.

29 Penjelasan Prof. Dr. Imam Bawani pada Stadium General "Perbandingan Pendidikan" tanggal 25 Nopember 2013.

90 | Tarbiyatuna: Jurnal Pendidikan Islam; Volume 11, Nomor 1, Februari 2018 p-ISSN: 2085-6539, e-ISSN
} 
dari sisi ilmu kegamaan ataupun ilmu pengetahuan umum seperti Olimpiade Sains. Kegiatan-kegiatan kependidikannya tak kalah menarik, mereka melakukan Summer Champ di China dan beberapa negara lain di luar negeri. ${ }^{30}$

Berdasarkan brosur pendaftaran yang penulis dapatkan. Pondok Pesantren Salafiyah Terpadu Ar-Risalah berdiri pada bulan Februari 1995. Terletak di Desa Lirboyo, Kecamata Mojoroto, Kota Kediri Jawa Timur. Berkaitan dengan standar mutu pendidikan, Pondok Pesantren Salafiyah Terpadu Ar-Risalah ini memiki saranaprasarana ruang studio radio Risalah FM, Asrama Puteri, Asrama Putera, Koprasi Puteri, Koprasi Putera, Musholla, Perkantoran, Auditorium, Perpustakaan, English Centre, Ruang Multimedia, Ruang Studio Video, Ruang Sekolah, Ruang Makan, Ruang Cuci Pakaian, Ruang Usaha Kesehatan Sekolah, Ruang Kesenian/Keterampilan, Laboratorium Bahasa, Laboratorium Komputer, Laboratorium Kimia Fisika, Laboratorium Biologi, Laboratorium Pengetahuan Sosial.

Uniknya Pondok Pesantren Salafiyah Terpadu Ar-Risalah memiliki kebijakan mutu pendidikan diantaranya: pertama, Membentuk Pribadi Luhur Yang Mampu Bersaing Secara Global; Pondok Pesantren Salafiyah Terpadu Ar-Risalah sangat mengedepankan Akhlaqul Karimah. Kedua, Mengutamakan Kebersihan; Pondok Pesantren Salafiyah Terpadu Ar-Risalah mendidik santrinya untuk selalu hidup bersih. Ketiga, Bangga Menjadi Santri; Pondok Pesantren Salafiyah Terpadu ArRisalah menanamkan rasa bangga terhadap santrinya karena status santri yang ia sandang itu sendiri. Keempat, Mengutamakan Kedisiplinan; Pondok Pesantren Salafiyah Terpadu Ar-Risalah setiap melakukan kegiatan selalu tepat waktu. Kelima, menggunakan pengamalan ilmu; Pondok Pesantren Salafiyah Terpadu Ar-Risalah mewajibkan kepada semua santrinya untuk melaksanakan sholat dhuha, tahajjud, hajat, dan sholat witir. Setiap senin dan kamis wajib puasa bagi santri tingkat SMP dan SMA. ${ }^{31}$

Fenomena lainnya ada di Kabupaten Sidoarjo; Pondok Pesantren Bumi Sholawat. Sama halnya dengan Pondok Pesantren Slafiyah Terpadu Ar-Risalah,

\footnotetext{
${ }^{30}$ www.arrisalah.org

31 Brosur pendaftaran Pondok Pesantren Salafiyah Terpadu Ar-Risalah.
} 
pondok pesantren KH. Agoes Ali Mashuri Tulangan ini juga mendirikan SMP Progresif yang memiliki prestasi berimbang antara pengetahuan umum dan pengetahuan agama. Di dalam buku pribadinya, KH. Agoes Ali Mashuri Tulangan menyebutkan pendirian lembaga pendidikan sekolah ini untuk menjawab kebingungan masyarakat yang anaknya pandai dan berprestasi, namun akhlaq dan spiritualitasnya gersang ${ }^{32}$. SMP Progresif pun terintegrasi dengan tradisi kepesantrenan-tradisional yang sangat kental. Berdasarkan pada standar kualitas mutu, sekolah ini memiliki sarana-prasarana yang memadai, gedung asrama dan sekolah yang mentereng, guru-guru yang profesional. ${ }^{33}$

Beberapa fakta di atas, merupakan beberapa pemahaman kiai dan pengembangan (dalam persepsi kesengajaan yang dilakukan pesantren) untuk menyesuaikan dengan kebutuhan zaman yang ada di masyarakat. Meskipun, penulis juga masih memiliki data lain, terkait dengan terma pengembangan pesantren dengan model; pertama, pesantren moving culture, yakni proses pengembangan pesantren ke beberapa pesantren cabang di daerah-daerah tertentu, Gontor dan Sidogiri misalnya. Kedua, pesantren yang dikembangkan melalui proses politik lokal; seperti, di beberapa daerah bersamaan dengan proses politik yang terjalin. Ketiga, pengembangan pesantren berbasis filantropisme. Misalnya, penyertaan modal masyarakat, sumbangan/donasi masyarakat, dan penwakafan tanah-tanah yang dimiliki masyarakat terhadap pesantren.

\section{Penutup}

Betapapun kepempinan pesantren - dalam sudut pandang pengembangan dan aspek kbijakan - tak selalu bermakna perubahan nomenklatur dari, salafiyah, modern, konfrehensif, integratif, dan penamaan-penamaan antropologis-sosiologis lainnya. Pada saatnya, pesantren akan membingkai citeranya sendiri berdasarkan pada basis keyakinan yang dibangun oleh para kiai, pengelola lembaga, dan interaksionisme pesantren dengan kebutuhan masyarakat. Pada intinya, nomenklatur kajian

\footnotetext{
32 KH. Agoes Ali Mashuri, Belajar Dari Lalat (Surabaya: Khalista, 2008), 34

33 www.sekolahprogresif.sch.id

92 | Tarbiyatuna: Jurnal Pendidikan Islam; Volume 11, Nomor 1, Februari 2018 p-ISSN: 2085-6539, e-ISSN
} 
kepesantren - meski sudah ditulis oleh ribuan peneliti - tidak akan kehabisan postulasi untuk menciptakan karakteristik yang baru pada aspek pembaruan sudut pandang sainstifik. Kesimpulannya, tulisan ini, ingin menunjukkan bahwa pesantren akan terus berkembang dan mengembangkan dirinya berdasarkan pada kepercayaan masyarakat terhadap pesantren tersebut.

\section{Referensi}

Alma , Buchori dan Ratih Hurriyati., Manajemen Corporate dan Strategi Pemasaran Jasa Pendidikan Fokus Pada Mutu dan Layanan Prima, Bandung; Alfabeta, 2009)

AM, Mukhlisah,. "Post-Standarisasi Kepemimpinan Pesantren" dalam Jurnal Kependidikan Islam, Vol. 2, No. 4.

Amrullah, A. M. Karim., Perubahan Model Penyelenggaraan Pendidikan Pesantren Disertasi-Universitas Malang, 2011.

Asrohah, Hanun, Transformasi Pesantren, Jakarta; Rineka, 2003.

Azra, Azyumardi, Pendidikan Islam: Tradisi dan Modernisasi Menuju Milenium Baru, Jakarta: Logos Wacana Ilmu, 1999.

B, Caldwell \& S Spinks., Leading the Self-Managing School, London: The Falmer Press. 1992.

Ball, Stephen., The Routledge Falmer Reader of Sociology of Education, New York; Routledge Falmer, 2004.

Bennis, Warren., On Become a Leader, Pheladelpia; Perceus Books Group, 2009.

Brosur pendaftaran Pondok Pesantren Salafiyah Terpadu Ar-Risalah.

Bush, Tony., "Educational leadership and management:theory, policy, and practice dalam South African", Journal of Education, Vol. 27, 2007.

Dimmock, Clive et,al., Educational Leadership; Culture and Diversity, London; Sage Publication, 2005.

Hoy, Wyne K. \& Scott R. Sweetland "Designing Better School; The Meaning and Measure of Enabling School Structure" dalam Jurnal Educational Administration Quarterly Vol. 37 No. 03

Hs, Mastuki, Kelas Menengah Santri, Jakarta; PPIM UIN Press, 2011.

Kasali, Rhenald., Change, Jakarta: Gramedia Pustaka Utama, 2005 
Leithwood, Kenneth A., What We Know About Succesfull School Leadership, UK; National College for School Leadership, 2003.

Leithwood, Kenneth A., What We Know About Succesfull School Leadership, UK; National College for School Leadership, 2003.

Makalah Simposium Internasional Madrasah In Global Context, Puslitbang Depag Tahun 2013, di Bekasi Jawa Barat.

Mardiyah "Kepemimpinan Kiai dalam Pemeliharaan Budaya Organisasi di Pondok Modern Gontor, Lirboyo Kediri, dan Pesantren Tebuireng Jombang”, Jurnal Tsaqafah Vol. 8, No. 12012.

Mardiyah, Kepemimpinan Kiai dalam Memelihara Budaya Organisasi, Malang: Aditya Media Publishing, 2012.

Mashuri, KH. Agoes Ali., Belajar Dari Lalat, Surabaya: Khalista, 2008.

Muhaimin, Manajemen Penjaminan Mutu di Universitas Islam Negeri Malang, Malang : UIN Malang, 2005.

Penjelasan Prof. Dr. Imam Bawani pada Stadium General "Perbandingan Pendidikan” tanggal 25 Nopember 2013.

Qomar, Mujamil., Menggagas Pendidikan Islam, Bandung: Rosdakarya, 2014.

Shodiq, Muhammad., Kepemimpinan Kiai Nasib dalam Meningkatkan Mutu Pesantren, Studi pada Pesantren Al-Hikam Malang, Pesantren Luhur AlHusna Surabaya, dan Pesantren Mahasiswa An-Nur Surabya”, DisertasiUniversitas Negeri Malang, 2011.

Subhan, Arief. Lembaga Pendidikan Islam Indonesia Abad ke-20, Jakarta: Kencana Prenada Media Group, 2012.

Tilaar, HAR. Pendidikan dan Kekuasaan, Jakarta: Rinneka Cipta, 2003.

Wyne K. Hoy \& Scott R. Sweetland "Designing Better School; The Meaning and Measure of Enabling School Structure", Jurnal Educational Administration Quarterly Edisi, Vol. 37, No. 3. 


\section{Internet}

\section{www.arrisalah.org}

www.sekolahprogresif.sch.id 